\title{
PENGALAMAN IBU HAMIL DALAM MENERAPKAN PROTOKOL KESEHATAN PADA FASILITAS KESEHATAN
}

\author{
Suwarti $^{1 *}$, Febi Ratnasari ${ }^{2}$, Lastri Mei Winarni ${ }^{3}$ \\ Sekolah Tinggi Ilmu Kesehatan Yatsi ${ }^{1 * 2,3}$ \\ watieraul01@gmail.com ${ }^{1 *}$
}

\begin{abstract}
ABSTRAK
Kasus pertama Covid-19 di Indonesia yang diumumkan pada tanggal 2 Maret 2020 menjadi awal dari munculnya kasus-kasus positif Covid-19 yang kian hari kian banyak.Virus Covid-19 dapat menyerang siapapun dan menyebabkan kematian bagi kalangan rentan seperti kelompok lanjut usia (lansia), pasien dengan riwayat penyakit akut, perokok, penghisap vape, kaum pria, dan orang bergolongan darah A. Namun, beberapa penelitian menyebutkan bahwa ibu hamil memiliki resiko yang berbahaya jika terinfeksi virus Covid-19, sehingga Ibu hamil dapat dikategorikan sebagai kategori rentan. Hal tersebut didukung dengan fakta bahwa selama masa kehamilan, ibu akan mengalami perubahan fisiologis baik pada kardiovaskular, pernapasan dan koagulasi sistem yang dapat meningkatkan resiko morbiditas Penelitian ini bertujuan untuk menggali lebih dalam mengenai pengalaman ibu hamil dalam menerapkan protokol kesehatan saat mengunjungi fasilita pelayanan kesehatan dalam rangka memeriksakan kandungan. Penelitian ini menggunakan metode kualitatif dengan pendekatan fenomenologi. Informan dalam penelitian ini merupakan $10 \mathrm{ibu}$ hamil yang dipilih menggunakan metode purposive sampling. Teknik pengumpulan data dilakukan dengan wawancara terstruktur dengan pendekatan collaizi. Hasil penelitian menunjukkan adanya beberapa tema yang disusun berdasarkan pengalaman yang diceritakan oleh pasien. Adapun tema tersebut terbagi menjadi tiga yaitu perbedaan prosedur pemeriksaan kehamilan sebelum dan saat pandemi Covid-19, perubahan pada aspek psikologis, fisik dan sosial, kebutuhan edukasi Protokol Kesehatan di Fasilitas Pelayanan Kesehatan. Simpulan penelitian didapatkan bahwa ibu hamil memiliki pengalaman yang hampir sama dalam menerapkan protokol kesehatan saat berkunjung ke fasilitas pelayanan kesehatan selama pandemi. Adapun saran dalam penlitian ini diperlukan studi lanjutan untuk memperdalam gambaran dan identifikasi tema penelitian.
\end{abstract}

Kata kunci : Ibu hamil, pengalaman, protokol kesehatan

\section{ABSTRACT}

The first case of Covid-19 in Indonesia which was announced on March 2, 2020 was the beginning of the emergence of positive cases of Covid-19 which were increasing day by day. The Covid-19 virus can attack anyone and cause death for vulnerable groups such as the elderly ( elderly), patients with a history of acute illness, smokers, vape smokers, 
men, and people with blood type A. However, several studies have stated that pregnant women have a dangerous risk if they are infected with the Covid-19 virus, so that pregnant women can be categorized as vulnerable. . This is supported by the fact that during pregnancy, the mother will experience physiological changes in the cardiovascular, respiratory and coagulation systems that can increase the risk of morbidity. check content. This study uses a qualitative method with a phenomenological approach. The informants in this study were 10 pregnant women who were selected using the purposive sampling method. The data collection technique was carried out by structured interviews with a collaizi approach. The results showed that there were several themes that were arranged based on the experiences told by the patients. The themes are divided into three, namely differences in pregnancy examination procedures before and during the Covid-19 pandemic, changes in psychological, physical and social aspects, educational needs for Health Protocols in Health Service Facilities. The conclusion of the study was that pregnant women had almost the same experience in implementing health protocols when visiting health care facilities during a pandemic. As for suggestions in this research, further studies are needed to deepen the description and identify the research themes.

\section{Keywords: Pregnant women, experience, health protocol}

\section{PENDAHULUAN}

Kasus pertama Covid-19 di Indonesia yang diumumkan pada tanggal 2 Maret 2020 menjadi awal dari munculnya kasus-kasus positif Covid-19 yang kian hari kian banyak. Pada bulan April 2020, jumlah kasus positif Covid-19 sebanyak 3.512 kasus yang tersebar di seluruh provinsi yang ada di Indonesia dengan 282 orang dinyatakan sembuh dan 306 orang meninggal dunia. Virus Covid-19 dapat menyerang siapapun dan menyebabkan kematian bagi kalangan rentan. Beberapa penelitian menyebutkan bahwa ibu hamil memiliki resiko yang berbahaya jika terinfeksi virus Covid19 karena selama masa kehamilan, ibu akan mengalami perubahan fisiologis baik pada kardiovaskular, pernapasan, dan koagulasi sistem yang dapat meningkatkan resiko morbiditas.
Ibu hamil perlu memeriksakan perkembangan kandungannya untuk memastikan bahwa janin tumbuh dengan baik dan sehat, oleh sebab itu perlu adanya kunjungan ke pelayanan fasilitas kesehatan. Pada masa pandemi Covid-19 tentu terdapat beberapa prosedur penyesuaian yang diterapkan oleh pemerintah yang berkaitan dengan pelayanan pada fasilitas kesehatan sesuai yang diatur dalam Keputusan Menteri Kesehatan Republik Indonesia Nomor : HK.01.07/MENKES/382/2020

Tentang Protokol Kesehatan Bagi Masyarakat Di Tempat Dan Fasilitas Umum Dalam Rangka Pencegahan Dan Pengendalian Corona Virus Disease 2019 (COVID-19). Selain itu, berdasarkan protokol petunjuk praktis layanan kesehatan ibu dan bayi baru 
lahir selama pandemi Covid-19 Nomor B-4 (05 April 2020) tertera bahwa salah satu kesiapan Fasilitas Kesehatan yaitu dengan melakukann edukasi kepada ibu hamil, ibu bersalin, ibu menyusui dan pengasuh agar patuh untuk menggunakan masker ketika berkunjung ke fasilitas kesehatan dan jujur menyampaikan status kesehatannya

Angka jumlah pasien Covid19 yang terus meningkat, menjadi alasan bagi pemerintah dalam memberikan himbauan tegas kepada masyarakat untuk tetap menerapkan protokol kesehatan ketat dengan tujuan mencegah penularan virus Covid-19. Ibu hamil sebagai salah satu kategori kelompok yang rentan terpapar virus Covid-19 perlu melakukan penyesuaian apabila hendak melakukan pemeriksaan kandungan di tengah pandemi Covid19. Penyesuaian tersebut dapat berupa jadwal kunjungan dan juga penerapan APD lengkap saat hendak berkunjung.

Tujuan penelitian untuk menggali dan memahami lebih dalam mengenai pengalaman ibu hamil dalam menerapkan protokol kesehatan ketat pada fasilitas pelayanan kesehatan

\section{METODE PENELITIAN}

Desain penelitian pada penelitian ini yaitu menggunakan pendekatan kualitatif, peneliti dapat mengamati temuan terkonsentrasi secara normal dengan memperhatikan secara langsung, memimpin pertemuan dengan orang-orang yang memiliki banyak data tentang keajaiban yang sedang diselidiki, dan mempertimbangkan berbagai catatan tentang keajaiban yang sedang diperiksa tanpa mengarahkan perhitungan yang terukur. (Streubert \& Carpenter, 2011).

Partisipan penelitian adalah Ibu hamil yang mendatangi fasilitas kesehatan Puskesmas Periuk Jaya untuk memeriksakan kandungannya selama Pandemi COVID-19 sebanyak 10 orang.

Kriteria Informan Kunci :

1. Merupakan Ibu hamil

2. Rutin melakukan pemeriksaan kandungan di Puskesmas Periuk Jaya dengan anjuran Tenaga Kesehatan di Masa Pandemi COVID-19

Metode pengumpulan informasi dalam penelitian ini meliputi:

1. Pengamatan

2. Wawancara

3. Dokumentasi

Alat bantu penelitian yang dipergunakan :

1. Panduan Wawancara Mendalam

2. Alat Pencatatan

3. Alat perekam Suara

Pengolahan Data dan Analisa

Data Setelah melakukan pengumpulan data melalui teknik observasi, wawancara dan studi dokumentasi, maka data yang sudah didapatkan kemudian diolah dan dianalisis. Pengolahan data dilakukan dengan membuat transkrip hasil wawancara (Verbatim). Berdasarkan jenis wawancara yang dilakukan yaitu wawancara mendalam, maka isi dari trasnkrip harus sama persis dan sesuai dengan yang direkam menggunakan alat perekam suara. 
Dalam membedah informasi pemeriksaan, analis menggunakan teknik Colaizzi.

Penelitian ini telah melalui uji etik dan telah dinyatakan lulus oleh Komite Etik STIKES YATSI Tangerang dengan Nomer Surat : 169/LPPM-STIKES YATSI/IX/2021.

\section{HASIL PENELITIAN}

Partisipan dalam penelitian ini sebanyak 10 orang ibu hamil yang dipilih berdasarkan kriteria inklusi yang sudah ditetukan pada bab sebelumnya. Semua ibu hamil yang menjadi partisipan dalam penelitian ini bertempat tinggal di wilayah kerja Puskesmas Periuk Jaya. Pengkodean partisipan diatas berdasarkan urutan wawancara yang dilakukan oleh peneliti sebanyak 10 orang dengan kode $\mathrm{P}$ sebagai partisipan yaitu $\mathrm{P} 1$, P2, P3, P4, P5, P6, P7, P8, P9, P10.

Proses menentukan tema dimulai dengan pengumpulan data, menyusun transkip verbatim, dan analisa data. Didapatkan tiga tema yang telah teridentifikasi melalui proses analisa data. Proses ini dilakukan dengan metode Colazzi dengan menggunakan content analysis untuk menemukan tematema penting dari data hasil wawancara yang menggambarkan perasaan, pemikiran dan persepsi partisipan atas pengalamannya dalam menerapkan protokol kesehatan ketat saat mengunjungi fasilitas pelayanan kesehatan untuk melakukan pemeriksaan kehamilan.

$$
\text { Dari hasil penelitian }
$$

didapatkan tiga tema :

\section{Tema 1 : Perbedaan Prosedur Pemeriksaan Kehamilan Sebelum dan Sesudah Masa Pandemi Covid- 19}

Tema ini didapatkan berdasarkan partisipan yang sudah mengambarkan dengan jelas mengenai perbedaan pelayanan pemeriksaan kehamilan di masa pandemi Covid-19 dan sebelum Covid-19 dengan penerapan protokol kesehatan

\section{Tema 2 : Perubahan Pada Aspek Psikologis, Fisik dan Sosial}

Tema ini didapatkan berdasarkan gambaran-gambaran perubahan-perubahan yang terjadi dan juga kecemasan saat mengunjungi fasilitas pelayanan kesehatan untuk memeriksakan kehamilan.

Perubahan Psikologis dirasakan oleh sebagian partisipan dalam penelitian. Perubahan psikologis yang dirasakan yaitu perasaan khawatir berlebih atau cemas, adanya rasa takut, dan juga rasa lelah yang berlebihan.

Perubahan fisik yang dirasakan oleh sebagian partisipan yaitu merasa kurang fit, penurunan aktvitas fisik.

Perubahan sosial yang dirasakan oleh sebagian partisipan berkaitan dengan rasa takutnya berbicara dengan orang lain atau sekedar berdekatan dengan orang lain.

\section{Tema 3 : Kebutuhan Edukasi Protokol Kesehatan di Fasilitas Pelayanan Kesehatan}

Tema ini didapatkan berdasarkan hampir semua partisipan 
memberikan pernyataan bahwa kepatuhan dalam menerapkan protokol kesehatan saat hendak mengunjungi Puskesmas didukung dengan adanya edukasi atau pemahaman yang dilakukan oleh petugas kesehatan dan sebagian lagi mempelajari nya dari berbagai macam poster dan juga spanduk yang tersedia di Puskesmas.

\section{PEMBAHASAN}

Hasil penelitian dan pembahasan yang dilakukan peneliti dapat menyimpulkan tentang bagaimana pengalaman pasien dalam menerapkan protokol kesehatan saat mengunjungi fasilitas pelayanan kesehatan yaitu Puskesmas Periuk Jaya. Peneliti akan menjelaskan tentang interpretasi dari hasil penelitian yang telah dilakukan dan keterbatasan yang ditemui dalam penelitian ini. Interpretasi hasil dilakukan dengan cara membandingkan hasil penelitian dengan tinjauan pustaka yang telah diuraikan pada bab sebelumnya.

Tema 1: Perbedaan Prosedur Pemeriksaan Kehamilan Sebelum dan Sesudah Masa Pandemi Covid19

Tema ini didapatkan berdasarkan partisipan yang sudah mengambarkan dengan jelas mengenai perbedaan pelayanan pemeriksaan kehamilan di masa pandemi Covid-19 dan sebelum Covid-19 dengan penerapan protokol kesehatan.

Penerapan protokol kesehatan bagi ibu hamil yang hendak melakukan pemeriksaan kehamilan sesuai dengan peraturan yang termuat dalam buku Pedoman Bagi Ibu hamil, Ibu Nifas, dan Bayi Baru Lahir selama Social Distacing (Kemenkes, 2020). Selain itu anjuran pemeriksaan kehamilan pada masa Pandemi Covid-19 sudah sesuai dengan tatalaksana persalinan dan kehamilan yang direkomendasikan oleh PP POGI (Kemenkes, 2020).

Tema 2 : Perubahan Pada Aspek Psikologis, Fisik dan Sosial

Terjadi perubahan dari diwajibkannya penerapan protokol kesehatan bagi ibu hamil saat mengunjungi fasilitas pelayanan kesehatan dalam rangka pemeriksaan kehamilan.

Sebagian partisipan mengalami perubahan penerapan secara psikologis, yaitu ditandai dengan rasa cemas dan khawatir secara berlebihan dan juga rasa lelah yang berlebihan. Namun, rasa stres, cemas, khawatir dan juga perubahan mood yang begitu cepat pada ibu hamil, bukan semata-mata karena kondisi Covid-19, hal tersebut dapat juga dipengaruhi oleh perubahan hormon pada masa kehamilan. Perubahan tersebut dipengaruhi meningkatnya hormon progesteron dan estrogen. Seperti yang dijelaskan dalam penelitian milik (Rahmawati, 2017)

Beberapa partisipan mengeluhkan rasa sesak nafas, munculnya ruam dan juga jerawat pada wajah karena harus penggunaan masker. Namun secara fisiologis, sesak nafas memang wajar terjadi pada ibu hamil terutama pada trimester ketiga yaitu adanya 
ketidaknyamanan fisik yang diakibatkan oleh perubahan fisik ibu hamil dan jerawat tersebut bisa saja merupakan akibat dari pengaruh hormon progesterone.

Menurut partisipan menghindari individu dan tidak melakukan interaksi apapun saat mengunjungi Puskesmas dan menunggu giliran pemeriksaan merupakan suatu contoh penerapan social distancing dalam mematuhi protokol kesehatan.

Tema 3 : Kebutuhan Edukasi Protokol Kesehatan di Fasilitas Pelayanan Kesehatan7

Edukasi yang didapatkan oleh partisipan terbagi menjadi dua kategori yaitu partisipan yang mendapatkan edukasi secara langsung dari petugas kesehatan dan partisipan yang mendapatkan edukasi dari alat peraga seperti poster dan juga spanduk yang tersedia di Puskesmas.

\section{SIMPULAN}

Berdasarkan hasil penelitian yang telah dilakukan maka didapatkan tiga tema:

1. Perbedaan prosedur pemeriksaan kehamilan sebelum dan sesudah masa pandemi Covid-19

2. Perubahan pada aspek psikologis, fisik dan social

3. Kebutuhan edukasi protokol kesehatan di fasilitas pelayanan Kesehatan.

\section{SARAN}

Diperlukan penelitian lanjutan yang dapat mengeksplorasi lebih mendalam terkait pengalaman ibu hamil dalam menerapkan protokol kesehatan pada saat mengunjungi fasilitas pelayanan kesehatan namun dari segi petugas kesehatan.

\section{DAFTAR PUSTAKA}

Afiyanti, F., \& Rachmawati. (2014). Metode Penelitian Kualitatif Dalam Riset Keperawatan. Raja Grafindo Persada.

Anggraeni, D. ., \& Saryono. (2013). Metodelogi Penelitian Kualitatif dan. Kuantitatif dalam Bidang Kesehatan. Nuha Medika.

Bungin, B. (2010). Metodologi Penelitian Kualitatif. Raja Grafindo Persada.

Dashraath P, Wong JLJ, Lim MXK, Lim LM, Li S, Biswas A, Choolani M, Mattar C, S. L. (2020). Special Report and pregnancy. Am J Obstet Gynecol, 222(6), 521-531.

Fauztihana, I., Khudayani, R., Qomarkan, M. W., Ariska, E., Widyastuti, P. S., \& Supriyanto, T. (2020). Keefektifan Penggunaan Hand Sanitizer Sebagai Pengganti Sabun dan Air Dalam Cuci Tangan Selama Pandemi Covid-19.

Kumalasari, I. (2015). Panduan Praktik Laboratorium dan Klinik PerawatanAntenatal,Intranatal, Postnatal, Bayi Baru Lahir dan Kontrasepsi. Salemba.

Megasari, M. (2015). Panduan Belajar Asuhan Kebidanan. Dee Publish.

Nurdamayanti, F., Riafisari, A. A., \& Semarang, M. (2020). Literatur Review : Komplikasi Kehamilan Pada Ibu Hamil yang Terinfeksi. Seminar Nasional Publikasi 
Hasil-Hasil Penelitian Dan

Pengabdian Masyarakat

Universitas Muhammadiyah

Semarang, 3, 703-710.

Polit, \& Beck. (2012). Resource Manual for Nursing Research. Generating andAssessing Evidence for Nursing Practice. Ninth Edition. Lippincott.

Pradana, A. \& casman. (2020). Pengaruh kebijakan. Pengaruh Kebijakan Social Distancing Pada Wabah Covid-19 Terhadap Kelompok Rentan Di Indonesia the, 09(02), 61-67.

Prawiroharjo, S. (2014). Ilmu Kebidanan. Yayasan Bina Pustaka.

Rahmawati, lisa dan M. prihatin ningsih. (2017). Gambaran Pengetahuan Ibu Hamil Tentang Perubahan Psikologis Kehamilan Di Wilayah Kerja Puskesmas Pariaman. Jurnal Ilmiah Kebidanan, 8 NO 1(February), 19.

Rasmussen, S., Sperling, P., Poulsen, M. S., Emmersen, J., \& Andersen, S. (2020). Medical students for health-care staff shortages during the COVID-19 pandemic. The Lancet, 395(10234), e79-e80. https://doi.org/10.1016/S01406736(20)30923-5

Rimadhani, M., \& Rahmadewi. (2015). Pengaruh Hormon terhadap Akne Vulgaris. BIKKK - Berkala Ilmu Kesehatan Kulit Dan Kelamin - Periodical of Dermatology and Venereology, 27(3), 218-224.

Saifullah, A. (2015). Hubungan
Tingkat Pengetahuan Perawat denganTtindakan perawat dalam manajemen Pyeri Pasien Post Op Operasi di Bangsal Bedah RSUD DR. Prijonegoro Soehadi Sragen. 1-73.

Septiyaningsih, R., Yunadi, F. D., \& Kusumawati, D. D. (2021). Edukasi Dalam Upaya Meningkatkan Kesehatan Pada Ibu Hamil Abstrak Bencana non alam berupa pandemi virus corona ( COVID-19) adalah masalah yang sedang dihadapi oleh banyak negara, termasuk Indonesia . Dampak buruk yang diakibatkan COVID-19 adalah kematia. Jurnal Pengabdian Masyarakat Al Irsyad, 3(1), 1-7.

Siagian, T. H. (2020). Mencari Kelompok Berisiko Tinggi Terinfeksi Virus Corona Dengan Discourse Network Analysis. Jurnal Kebijakan Kesehatan Indonesia, 09(02), 98-106.

Streubert, H. ., \& Carpenter, D. R. (2011). Qualitative Research in Nursing Advancing the Humanistic Imperative. Wolters Kluwer .

Sukarni, I., \& Wahyu, P. (2013). Buku Ajar Keperawatan Maternitas. Nuha Medika.

Sunarsih, T. (2011). Asuhan Kebidanan Ibu Nifas. Salemba Medika.

Sunarti. (2013). Asuhan kehamilan. In Media.

Susilo, A., Rumende, C. M., Pitoyo, C. W., Santoso, W. D., Yulianti, M., Herikurniawan, H., Sinto, R., Singh, G., Nainggolan, L., Nelwan, E. J., Chen, L. K., 
Widhani, A., Wijaya, E., Wicaksana, B., Maksum, M., Annisa, F., Jasirwan, C. O. M., \& Yunihastuti, E. (2020). Coronavirus Disease 2019: Tinjauan Literatur Terkini. Jurnal Penyakit Dalam Indonesia, $\quad 7(1), \quad 45$. https://doi.org/10.7454/jpdi.v7i1. 415

Tang, W., Shao, X., Chen, Q., Zhu, L., He, Y., \& Lu, E. (2021). Nutritional status of protein intake in severe pneumonia patients based on dietary nutrition information system. Journal of Infection and Public Health, 14(1), 66-70. https://doi.org/10.1016/j.jiph.201 9.07.016

Wardhani, D. F. (2012). Hubungan Tingat Kebersihan Rongga Mulut Dengan Status Gingiva Pada Ibu Hamil Di Wilayah Kerja Puskeswmas Sumbersari Kecamatan Sumbersari Kabupaten Jember. Universitas Jember.

Yan, G., Lee, C. K., Lam, L. T. M., Yan, B., Chua, Y. X., Lim, A. Y. N., Phang, K. F., Kew, G. Sen, Teng, H., Ngai, C. H., Lin, L., Foo, R. M., Pada, S., Ng, L. C., \& Tambyah, P. A. (2020). Covert COVID-19 and falsepositive dengue serology in Singapore. The Lancet Infectious Diseases, 20(5), 536. https://doi.org/10.1016/S14733099(20)30158-4

Yuliana A. (2015). Dukungan Suami Pada Ibu Hamil dalam Menghadapi Masa Persalinan di
Desa Joho Kabupaten Sukoharjo. Maternity: Jurnal Kebidanan dan Ilmu Kesehatan. Jurnal Kebidanan Dan Ilmu Kesehatan, 2(2), 1-7.

Zhang, H., Penninger, J. M., Li, Y., Zhong, N., \& Slutsky, A. S. (2020). Angiotensin-converting enzyme 2 (ACE2) as a SARSCoV-2 receptor: molecular mechanisms and potential therapeutic target. Intensive Care Medicine, 46(4), 586-590. https://doi.org/10.1007/s00134020-05985-9 